\title{
Personal Web Use in the Workplace: Why Does It Persist in a Context of Strict Security and Monitoring?
}

\author{
Andrea M. Polzer-Debruyne ${ }^{1}$, Micheal T. Stratton ${ }^{2} \&$ Gary $_{\text {Stark }}^{3}$ \\ ${ }^{1}$ School of Psychology, Massey University, Auckland, New Zealand \\ ${ }^{2}$ Department of Management and Accountancy, University of North Carolina Asheville, USA \\ ${ }^{3}$ College of Business, Northern Michigan University, Marquette, Michgan, USA \\ Correspondence: Micheal T. Stratton, Department of Management and Accountancy, University of North Carolina \\ Asheville, USA. E-mail: mstratto@unca.edu
}

Received: March 11, 2014

Accepted: April 4, $2014 \quad$ Online Published: April 30, 2014

doi:10.5430/ijba.v5n3p1

URL: http://dx.doi.org/10.5430/ijba.v5n3p1

\begin{abstract}
Over the last decade, Personal Web Use (PWU) in the workplace has received considerable attention. This study examined factors that both inhibit and encourage PWU behaviors. The context was a municipal government agency in the U.S. with strong policy and electronic restrictions on PWU. Our study builds on extant research by investigating both self-reported PWU (from an online survey of 116 users at the agency) and objective reports from the agency's electronic monitoring (EM) of PWU. Results of our hypothesis tests indicated that group norms, individual moral norms, and perceived time availability had an effect on PWU while boredom had no effect. Group norms moderated individual moral norms' effect on PWU. Discrepancies between individuals' self-reports and the agency's electronic reports of PWU are explained in terms of differing perceptions of what defines PWU. We describe implications important to both scholars and practitioners.
\end{abstract}

Keywords: managerial control, Personal Web Use (PWU), cyberloafing, electronic monitoring

\section{Introduction}

Work productivity is an eternal concern in organizations. Contemporary workers experience numerous distractions, not the least of which is personal web use (PWU) (Anandarajan \& Simmers, 2002; Lim, Teo \& Loo, 2002; Mirchandani \& Motwani, 2003). This behavior is defined as using the Internet for non-work-related activities on employer-provided devices (Mahatanankoon, Anandarajan \& Igbaria 2004). Beyond reduced productivity, concerns about PWU include such perceived counterproductive consequences such as cyber bullying (e.g. Benesch, 2011; Blumenfeld, 2005), data security vulnerability (Gordan, Loeb, Lucyshyn, \& Richardson, 2005; Richardson, 2003; Richardson, 2008), and reduced task focus (Mastrangelo, Everton, \& Jolton, 2006) have been of interest to scholars and practitioners alike. Recent findings (e.g., Belicove, 2011; Garrett \& Danziger, 2008; Kim \& Byrne, 2011; Malchowski \& Simonini, 2006; Mattioli, 2013; Polk-Lepson Research Group, 2013; Ugrin \& Pearson, 2013; Vitak, Crouse \& LaRose, 2011) reveal that PWU is a source of workplace disruption and that managers remain committed to minimizing the perceived counterproductive consequences using policies, electronic monitoring (EM), training, and disciplinary actions.

PWU behaviors by public sector employees in the United States (U.S.) have received particular attention (e.g., Stratton, 2010). Given the responsibility of public managers to ensure high performance and accountability to the citizenry (Nalbandian, O’Neill, Wilkes, \& Kaufman, 2013; Pina, Lourdes, \& Royo, 2010), some elected officials see PWU as the poster-child for an inefficient bureaucracy bloated with public servants seemingly unaccountable for their non-work behaviors. For example, various legislative oversight bodies have investigated both the Internal Revenue Service (Milbourn III, 2003) and the Department of Interior (Devaney, 2006) for continued and excessive PWU by agency staff. In addition, federal employees and private sector contractors at both the Securities and Exchange Commission and the National Science Foundation were investigated, and some disciplined, for frequently visiting sexually explicit websites (McElhatton, 2009; 2010). Those who call for stricter controls (e.g. KensingtonSwan, 2003) support tracking the frequency of PWU using commercially available EM software (Ugrin \& Pearson, 2013; Vorobyov, 2005). However, why does PWU persist when users are aware of it either being 
frowned upon, controlled, or clearly forbidden? In order to answer this question, the central purpose of our empirical study is to examine such factors that may contribute to PWU in a context of severely restrictive monitoring.

\subsection{Enablers and Inhibitors of Personal Web Use}

While researchers tend to measure PWU through self-report surveys of employees, organizations typically identify violations of their own electronic use policies through reports compiled by various EM systems. Examining multiple measures of PWU (self-report and as measured by the organization's EM system) may inform our understanding of why employees' PWU persists in monitoring-rich contexts. Many scholars agree that extant research is limited because of its overreliance on self-report survey data without regard for objectively reported PWU activity (e.g., Blanchard and Henle, 2008; Eastin, Glynn \& Griffiths, 2007; Lee, Lee \& Kim, 2004; Lim, 2002; Mahatanankoon, Anandarajan \& Igbaria, 2004; Manrique De Lara, 2006; Shaw \& Gant, 2002; Ugrin \& Pearson, 2013). Lim (2002) suggested that, "future studies should further reduce the potential of common method bias by supplementing the self-reports with reports from other sources" (p. 691). Blanchard and Henle (2008) also echoed the importance of measuring PWU through "monitoring software or peer reports" (p. 395). In an attempt to respond to these suggestions we will examine the degree to which PWU behaviors, as measured both by self-report and the EM system, are influenced by a number of determining factors in a highly monitored workplace context.

Researchers and practitioners are interested in why some employees engage in PWU more than others. The common thread found in the pioneering PWU literature (e.g. Anandarajan, Simmers \& Igbaria, 2000; Anandarajan \& Simmers, 2002; Blau, Yang \& Ward-Cook, 2004; Lee, Lee \& Kim, 2004; Lim, 2002) is the notion that PWU is influenced by a combination of both personal and workplace characteristics. Previous research has identified a number of influences that appear to 'push' individuals toward increased PWU, such as boredom (Eastin, Glynn \& Griffiths, 2007; Polzer-Debruyne, 2008), or certain work group norms that are favorably towards PWU (Mahatanankoon \& Igbaria, 2004; Stratton, 2006). However, factors enabling users to engage in behaviors are countered to some degree by restrictions to these behaviors 'pulling' them away from PWU. The degree to which an employee engages in PWU is then the consequence of having internally considered both the enabling and restricting influences. Such restrictions (or inhibitors) can be a function of the work environment (e.g., workload) (Lee, Lee \& Kim, 2004), as well as come from the individual (e.g., moral obligation) (Anandarajan \& Simmers, 2002).

In this study we investigate 'enablers' and inhibitors' and their impact on differences in individuals' PWU. Each of the enablers and inhibitors were selected with the aim of complementing previous PWU research and expanding it into the arena of public sector organizations in particular. Care was also taken to ensure that influences from within the person (i.e. boredom and own moral norms with regards to PWU) as well as influences from the environment (i.e. time to engage, work group norms regarding PWU) were included in the investigation.

\subsection{Research Hypotheses}

\subsubsection{Factors That Enable PWU: Boredom and Workgroup Norms}

Boredom is not, contrary to popular belief, a result of having nothing to do. It is very difficult to come up with a situation where a person's options are so limited that he or she can literally do nothing. Instead, boredom occurs in situations where none of the possible things that a person can do appeal realistically or give meaning to his or her activities (Svendsen, 2005). In general, boredom leads to high levels of frustration (Hill \& Perkins, 1985). Sensory deprivation studies (e.g. Solomon, 1961) indicated that the experience of monotony is frustrating to most people, and that when monotony is subjectively experienced they will seek additional or alternative stimulation. Bruursema, Kessler, and Spector (2011) confirmed that boredom could lead to counterproductive workplace behavior as a form of alternative stimulation. In an earlier survey study asking why individuals engage in personal web use, 19\% of respondents stated that they engage in PWU because they are bored or because their work lacks interest and stimulation (Polzer-Debruyne, 2008).

The meaning of boredom, however, is not limited to the experience of monotony. Barbalet (1999), for example, suggested that individuals experience boredom when they feel their actions or circumstances are without purpose or meaning. A particular characteristic of boredom is the associated feeling of timelessness. The absence of meaning for an activity promotes consciousness of time as an empty interval, regardless of how 'busy' one is. The subsequently perceived discrepancy between the work being seen as slow and irksome, and the mind wanting to be somewhere else, leads to boredom (Fraisse, 1963). Employees experiencing boredom with their work task, regardless of the existing workload, will abandon the task and dispel the boredom by literally or figuratively leaving the situation in order to find desired levels of stimulation and meaning (Hill \& Perkins, 1985). Previous research indicates that 
workplace boredom, regardless of workload, relates to increased self-reactive incentive to boredom, which in turn relates to increased PWU for some employees (Eastin, Glynn \& Griffiths, 2007; Polzer-Debruyne, 2008).

For other employees, PWU may be akin to escape conditioning, a form of negative reinforcement (Skinner, 1938). Engaging in PWU may not necessarily provide meaning and excitement, but it may remove the aversive stimulus of boredom presented by one's current work task. For example, when bored at work, one may scroll through pages of an online auction site just to look what is on offer in certain auction categories. Few will argue such casual window-shopping provides meaning and excitement. What it may provide, however, is temporary escape from an even more boring work situation (Stratton, 2006; 2010).

Boredom can, therefore, potentially exert a push-like effect to engage in PWU either as means to pass the time, to create meaning in a meaningless workday, or to provide excitement. In support of these arguments, Eastin and colleagues (2007) and Polzer-Debruyne (2008) found that employees with high levels of boredom at work are likely to engage in PWU more frequently than employees who felt their work to be stimulating, challenging and were, in general, not bored with their work. In this study we extend this hypothesis into the context of public administration while measuring PWU with both self-report and EM. We expect to see a significant, positive relationship between boredom and PWU.

Hypothesis 1: Higher levels of perceived boredom are positively related to higher levels of PWU.

It has been argued (e.g. Sherif, 1961) that in social contexts group norms are some of the most powerful determinants of one's actions. Work is part of a person's social context, and consequently work group norms can be powerful influences on one's work-related behaviors such as PWU. As employees scan their work environment for indicators of appropriate Internet use behaviors, they are likely to be influenced by acts of PWU they observe in their social comparison group (Festinger, 1954; Goethals, 1986), which typically would be their work group. Work groups, in turn, have norms that are the informal rules or standards adopted by the group to regulate and normalize the behavior of group members (Feldman, 1984).

Theoretical perspectives besides social comparison theory (Festinger, 1954) that support the idea that group norms influence behavior include the 'social learning' theory (Bandura, 1977) and 'social information processing' theory (Salancik \& Pfeffer, 1978). Social learning theory suggests that group members serve as role models for the individual planning his or her actions and anticipating consequences (Stajkovic \& Luthans, 1998). Social information processing theory posits that individuals use information from their immediate work group to interpret events, develop appropriate behaviors, and understand expectations concerning their behavior and consequences.

Past studies suggest that if members of the work group engage in PWU, a social cue emerges that communicates normative approval for such behavior (Blanchard \& Henle, 2008; Greenberg \& Scott, 1996; Lee, Lee \& Kim, 2004; Mahatanankoon \& Igbaria, 2004; Polzer-Debruyne, 2002; Stratton, 2006; 2010). Thus workgroup norms can exert, theoretically, a 'push' toward engaging in PWU (i.e., 'everyone else does it, so why shouldn't I do it?' or 'oh come on, there is nothing wrong with it'). In this study we extend the influence of group norms into the context of PWU within public administration while measuring PWU with both self-report and EM. We expect that work groups with members approving of and/or engaging in PWU can have an enabling effect towards PWU for the individual.

Hypothesis 2: Work group norms favorable toward PWU are positively related to higher levels of PWU

\subsubsection{Factors That Inhibit PWU: Personal Moral Norms and Time Availability}

"I know there are people at work who do that [PWU], but I don't think that's right" (Polzer-Debruyne, 2002, p. 7). This belief that a particular behavior is 'right' or 'wrong' is an individual's personal moral norm. It can be defined as the individual's perception of the moral correctness or incorrectness of engaging in the behavior (Conner \& Armitage, 1998). Ajzen (1991) and Schwartz and Tessler (1972) suggest that in certain contexts, moral obligations to perform, or refuse to perform certain activities, need to be considered along with other aspects influencing these actions. Norm-activation theory (NAT) (Schwartz, 1977) suggests that individuals adopt specific behaviors out of the conviction that they feel a moral obligation to do so. It is possible then that individuals refrain from PWU in response to their moral norms. One of the influences common to a number of previous studies into PWU is the idea that personal morals and ethics play a role in deciding whether to engage in PWU (Anandarajan, Simmers \& Igbaria, 2000; Anandarajan \& Simmers, 2002; Blau, Yang \& Ward-Cook, 2004; Lee, Lee \& Kim, 2004; Lim, 2002). The single strongest direct influence on PWU in Anandarajan and Simmers' (2002) study was the moral and ethical beliefs a person held about PWU, suggesting that these beliefs appeared to reduce PWU. These findings are in line with those of other authors (e.g., Banerjee, Cronan \& Jones, 1998; Gordon \& Qingxiong, 2003; Leonard, Cronan \& 
Kreie, 2004) who suggest that moral judgments and personal normative beliefs discourage users from engaging in technology-related behaviors that contradict related moral obligations.

Based on the theoretical and empirical reasoning and results from previous research we conceptualize personal moral norms regarding PWU as an important influence on actual PWU.

Hypothesis 3: Individuals' moral norms unfavorable to PWU are negatively related to the same individuals' level of PWU.

PWU is an activity engaged outside the normal job requirements, and thus is in addition to, or instead of, accomplishing the regular workload associated with the job. Individuals may experience a degree of restriction to engage in PWU, depending on time available to engage in PWU. Bellman, Lohse and Johnson (1999), and Lee, Lee and Kim (2004) found high workload, with its associated time demands on individuals, to be a barrier to PWU frequency and duration. Again, we extend these variables into the context of public management while measuring PWU with both self-report and EM.

Hypothesis 4: Lower perceived time availability is negatively related to PWU.

\subsubsection{Relationships between Enablers and Inhibitors}

When navigating the perceived morality of PWU at work, individuals do not rely on their own personal norms alone. When combining the forces of one's own moral norms about engaging in PWU with those perceived to exist in one's work group, one can potentially experience a 'push-and-pull' effect that directs decisions to engage in such behavior. PWU scholars Anandarajan and Simmers (2002) applied the Theory of Planned Behavior (Ajzen, 2002) to argue that personal moral norms are the strongest influence on PWU and that social expectations (e.g., work group norms) may play a role, although to a lesser extent. It was of interest to us to examine whether the strength or direction of one's own moral norms can be moderated by work group norms. Hence we examine whether the hypothesized inhibiting effect of one's own personal norms on PWU is lessened by the hypothesized enabling norms of one's work group.

Hypothesis 5: The impact personal norms have on PWU is moderated by perceived work group norms regarding PWU.

According to psychological theories of workplace motivation (cf. Barbuto \& Scholl, 1998), organisms strive to increase pleasurable stimulation and to decrease aversive experiences. It is reasonable to think then that individuals who feel 'enabled' by their boredom to engage in the more pleasurable activity of PWU simultaneously feel 'inhibited' to do so by existing and perceived time constraints. Engaging in PWU despite these inhibiting time constraints may then negate the expected pleasure or escape of engaging in PWU through resulting in additional stress or strain due to time-related pressures. We expect that the hypothesized enabling effect of PWU coming from boredom will be reduced in strength by the inhibiting aspects of one's time available for PWU.

Hypothesis 6: The relationship between boredom and PWU will be moderated by time available to engage in PWU.

\section{Method}

\subsection{Respondents}

Data were gathered through an online questionnaire sent to 249 employees of a small county government municipality in the northeastern United States. With site approval, the online questionnaire was available to employees for one month, and weekly reminders were sent to those who had not yet participated. Of the 249 employees approached to participate in this new study, 124 responded ( $47 \%$ response rate) and data from 116 fully completed surveys were used. Respondents consisted of 35 males $(30 \%)$ and 80 females (69\%) with one person declining to indicate his/her gender. The ages given by respondents ranged from 23 to 76 years, with an average age of 46 years and median age of 48 years. About half of the respondents held managerial or supervisory positions $(\mathrm{N}=56)$; while nearly one third $(\mathrm{N}=33)$ described themselves as non-supervisory professionals, $89 \%$ of respondents indicated they had been in their current positions for over 12 months.

\subsection{Research Context}

At the time of data collection this particular municipal government instituted both policy and monitoring technologies to curb the increase in non-business related Internet activity by users, including both managers and employees. Municipal leaders voiced concerned about threats to information security due to potentially both benign and malignant PWU. There was cause for concern after various incidents occurred that indicated inefficient use of taxpayer resources (i.e., municipal employees using hours each day to plan vacations or shop). In addition, some 
PWU such as music downloads from third-party sites were reducing bandwidth availability and exposing the network to security vulnerability.

An enterprise-wide policy was developed by the Information Technology (IT) Department and signed by all users. The policy stated that, "It is not acceptable to use the organization's networking facilities for activities unrelated to the organization's mission; for activities unrelated to official assignments and/or job responsibilities; and for any activity meant to foster personal gain." Subsequently, the organization's official position on Internet usage was clear and frequently shared with users. The EM system was restrictive and detailed in its surveillance capabilities. Essentially, all aspects of user activity were monitored, including when a specific site was visited. In addition, the IT Department determined which sites were deemed inappropriate and unrelated to government business, and hence fell under the organization's definition of non-work-related Internet activity.

Employees were regularly made aware of not only the policy, but also the monitoring system. When visiting a blocked website, a window appeared on their screen informing them that the particular site was in violation of policy and access was being blocked. Exemptions to these rules where possible on occasion if the employee and his/her supervisor made a convincing case to management and IT for having a certain website 'freed' for that particular person as it was seen to be role-relevant. When developing the survey for this study, a list of types of websites was included that have been shown in previous research to be seen as typical PWU websites by employees (Anandarajan \& Simmers, 2004; Anandarajan, Paravatsu \& Simmers, 2006; Polzer-Debruyne, 2002) and that had been identified by the organization as explicitly blocked. The reason for the inclusion of this list was to assist respondents to focus their attention on the website types that were blocked by the organization when thinking of their own PWU behaviors.

\subsection{Variable Design and Measures}

\subsubsection{Dependent Variables}

PWU was measured in terms of self-report and electronic monitoring. We explored how often respondents estimated their PWU or attempted PWU in an average week through a single multiple-choice question ("Can you please give an estimate how often you access or try to access the Internet at work for personal interest in an average week?"). This question offered the respondents 11 response options ranging from 'never' to 'over 70 times'. A similar question asking respondents to estimate their Internet access was used by Anandarajan, Simmers \& Igbaria (2000).

Past research repeatedly suggested that social desirability bias in self-reported PWU to be rather unlikely (Couper, 2000; Joinson, 1999; Kiesler \& Sproull, 1986). However, no previous research has investigated this, or any possible relationship between EM-reported PWU and self-reported PWU. In this study we therefore also included an EM-based PWU measure. EM-reported PWU was measured using data from the month prior to the survey and the month after the survey. EM-reported PWU data were provided by the organization through a summary report of actual, recorded PWU for each research participant. This report included the actual number of sites visited by each person, those blocked, as well as those permitted via security override by supervisors for one month before the survey, during the month of the survey, and one month after the survey. Research respondents were not required to provide consent to electronic monitoring because it was a well-published practice at individual workstations and was also a condition of employment, along with being a matter of public record. This suggests that reactivity should not be a concern for this measure. Because we were unable to confirm the relevance of every Internet access for each research participant, the decision was made to measure EM-reported PWU as the number of blocked attempts to access a website. This was in line with the organization's definition of PWU (mentioned previously in this paper).

Respondents' EM-reported average weekly PWU was extracted from the organization's monthly summary reports collected two months prior to administration of the survey and two months after the survey had closed. We had no control over who would be electronically monitored nor when and which Internet sites were deemed acceptable for which participant. Respondents were informed that the researchers would have access to the reports. These EM-reports were given from the organization's IT department to the researchers who then identified the survey respondents by their respective unique access IDs (network usernames). Respondents were asked to voluntarily indicate their usernames on the survey and were fully informed that their confidentiality would be fully protected. The monthly EM summary reports showed the frequencies of blocked website access per week. The summary reports during the survey month were not included to avoid potential Hawthorne effects. To investigate whether the survey did have an influence on participant PWU a paired sample t-test was conducted between the two sets of EM-reports used in the current study. The difference between the mean at Time 1 (Mean = 4.42) and Time 2 (Mean $=4.70)$ was not significant $(\mathrm{t}(88)=-0.98, \mathrm{p}=0.33)$ suggesting the survey did not have an influence on EM-measured PWU. 
Respondents' survey responses and their EM reports were matched based on their unique access ID's (usernames). To increase confidentiality, only the first author (based outside the U.S. and unknown to the organization) had access to personal information as well as the survey responses. Any data that could have potentially identified individuals were deleted after data analysis.

\subsubsection{Independent Variables}

To investigate the extent of respondents' boredom with their current work (Hypotheses 1 \& 6), eight items from Lee's (1986) measure of boredom on the job were used. The coefficient alpha of the eight-item boredom measure was .923 , indicating the workplace boredom measure had high reliability. High scores on this scale (1-5) indicated that the respondent often perceived work to be boring.

The perceived work group norms regarding PWU (Hypotheses $2 \& 5$ ) were examined through four questions. These questions were modified versions of items traditionally used in research examining moral norms in the theory of planned behavior (e.g., Ajzen, 2002a; Anandarajan, Simmers \& Igbaria, 2000; Beck \& Ajzen, 1991). The asked respondents about their supervisors' and colleagues' acceptance of the respondents' PWU and about their supervisors' and colleagues' own PWU. The coefficient alpha for this four-item measure was .812 indicating the measure had high reliability. High scores on this seven-point Likert scale indicated group norms favorable toward PWU.

Individual norms regarding PWU (Hypotheses $3 \& 5$ ) were examined through three questions. The three questions were modified versions of similar questions used to measure moral norms in previous studies (Beck \& Ajzen, 1991; Conner \& McMillan, 1999). The coefficient alpha of this measure in the current study was .900, indicating the measure's high reliability. High scores on this seven-point Likert scale indicated strong personal norms against PWU.

Perceived time availability (Hypotheses $4 \& 6$ ) was measured using a single question, "I simply don't have the time to access the Internet at work for personal interests". High scores on this seven-point Likert scale indicated little time to engage in PWU.

The use of single-item questions in surveys is frequently debated in psychometrics (e.g. Braithwaite \& Scott, 1991). In spite of the disadvantages that tend to be associated with them, single-item measures are regularly utilized, for example, as measures of job satisfaction (Nagy, 2002). These measures can, when used appropriately, reduce ambiguity and the need for second-guessing for the respondent, without having appreciable measurement loss (Barrett, 2002).

\subsubsection{Statistical Analyses}

Descriptive statistics of all variables were calculated to assess skewness and violations of normality. Pearson's correlations were performed on the dependent and independent variables to test for multicolinearity. We used t-tests to measure the similarity between self-reported PWU frequencies and EM-reported PWU. Hypotheses 1-4 were tested through stepwise regression analysis. The moderating variable hypotheses $(5 \& 6)$ were tested using ordinary moderated hierarchical regressions (Jaccard, Turisi and Wan, 1990). The regressions were conducted in two steps, whereby the main effects were entered in the first step (testing for their relationships with each other), and the product terms representing the interactions were entered in the second step. The presence of effects was indicated by statistically significant regression coefficients with an alpha of .05 . The regressions for the two PWU variables (self-reported and EM-reported) were conducted separately.

\section{Results}

\subsection{Summary Statistics}

A difference in means and standard deviations is noticeable between the two dependent variables. The average weekly, self-reported PWU ranged from 1-6 access attempts with a mean of 2.16 (stdv .99). The average weekly EM-reported PWU frequency ranged from 1-10 access attempts with a mean of 4.46 (stdv. 2.98).

Self-reported and EM-reported PWU had a moderate, positive correlation $(\mathrm{r}=.46, \mathrm{p}<.01)$. However, the difference of under-reporting of, on average, 2.23 PWU attempts was statistically significant $(\mathrm{t}(99)=-8.35, \mathrm{p}<.001)$. 
Table 1. The means, standard deviations and skew of PWU frequencies measured, and the hypothesized influencing variables $(\mathrm{n}=116)$

\begin{tabular}{lccc}
\hline & Mean & $\begin{array}{c}\text { Standard } \\
\text { deviation }\end{array}$ & Skew \\
\hline $\begin{array}{l}\text { Self-reported PWU } \\
\text { frequencies }\end{array}$ & 2.16 & .99 & .418 \\
$\begin{array}{l}\text { EM reported PWU } \\
\text { frequencies }\end{array}$ & 4.46 & 2.98 & .863 \\
Boredom & 1.94 & .99 & 1.15 \\
Moral norm & 3.95 & 1.54 & -.49 \\
Group PWU norms & 2.47 & 1.78 & .267 \\
No time for PWU & 4.54 & 1.46 & -1.03 \\
Guidelines prevent & 4.06 & 2.11 & -.855 \\
EM prevents & 3.51 & 2.08 & -.476 \\
\hline
\end{tabular}

Table 1 shows that, on average, the group of respondents reported relatively low levels of boredom at work (mean 1.95, stdv. .99) and held mildly approving views of PWU (mean = 3.95; stdv 1.54), although they perceived their workgroups to be relatively disapproving of it (mean $=2.47$; stdv 1.78$)$. On average the respondents indicated that typically they had no time to engage in PWU (mean $=4.54$; stdv 1.46).

\subsection{Hypotheses Testing}

Table 2. Pearson $-\mathrm{r}$ correlation coefficients of PWU frequencies reported and measured, and the hypothesized influencing variables

\begin{tabular}{lccccccc}
\hline & $\begin{array}{l}\text { EM-reported } \\
\text { PWU } \\
\text { frequencies }\end{array}$ & Boredom & $\begin{array}{l}\text { No time } \\
\text { for PWU }\end{array}$ & $\begin{array}{l}\text { Moral } \\
\text { norm }\end{array}$ & $\begin{array}{l}\text { Group } \\
\text { norm }\end{array}$ & $\begin{array}{l}\text { EM } \\
\text { prevents }\end{array}$ & $\begin{array}{l}\text { Guidelines } \\
\text { prevent }\end{array}$ \\
\hline $\begin{array}{l}\text { Self-reported PWU } \\
\text { frequencies }\end{array}$ & $.462^{* *}$ & .023 & -.168 & $-.377^{* *}$ & $.366^{* *}$ & .121 & .003 \\
$\begin{array}{l}\text { EM-reported PWU } \\
\text { frequencies }\end{array}$ & - & -.029 & $-.232^{*}$ & $-.361^{* *}$ & $.265^{* *}$ & .014 & .126 \\
$\begin{array}{l}\text { Boredom } \\
\text { No time }\end{array}$ & & - & $-.307^{* *}$ & -.120 & -.092 & .066 & .038 \\
Moral norm & & & - & $.579^{* *}$ & -.090 & .091 & .100 \\
Group norm & & & & - & $-.275^{* *}$ & .026 & $.311^{* *}$ \\
EM prevents & & & & & - & $.255^{*}$ & .117 \\
Guidelines prevent & & & & & & - & $.383^{* *}$ \\
\hline
\end{tabular}

Notes: $* * \mathrm{p}<.001 ;{ }^{*} \mathrm{p}<.01,(\mathrm{n}=116)$

Contrary to H1, workplace boredom did not have the expected significant relationship with self-reported $(r=.023, p$ $=.61)$ or EM-reported PWU ( $r=-.029, \mathrm{p}=.07)$.

In support of $\mathrm{H} 2$, there was a positive relationship between each PWU measures and work group norms $(\mathrm{r}=.366$ for self-reported, $\mathrm{r}=.265$ for EM-reported).

In support of $\mathrm{H3}$, those employees who morally approved of PWU self-reported more PWU $(r=-.377, \mathrm{p}<.01)$ and showed higher EM-reported PWU $(r=-.361, \mathrm{p}<.01)$ than their disapproving counterparts.

There was partial support for H4. Perception of low time availability for PWU had a significant negative relationship only with EM-measured PWU $(r=-.232, \mathrm{p}<.01)$. Its relationship with self-reported PWU was $\mathrm{r}=-.168(\mathrm{p}=.08)$.

The interaction hypotheses (H5 \& H6) were tested through two sets of moderated hierarchical regression analyses, one set for each criterion variable. Step 1 of the analysis shows the influence each variable has on PWU measured 
through self-report and PWU measured through EM. Step 2 then shows the results for the hypothesized interactions. In moderated hierarchical regression analysis the interaction terms are represented by product terms. These were found by creating the product terms for each pair of proposed predictor variables.

Multivariate normality was evaluated graphically by plotting, for each of the regression analyses, the residual scores in histograms with superimposed normal curves. The histograms showed satisfactorily normal distributions.

Table 3. Results of moderated hierarchical regression analyses to test the influences of boredom, availability (time to engage in PWU), electronic monitoring, PWU guidelines, moral norms, and work group norms on Personal Web Use (PWU) frequencies measured through self-report and through electronic monitoring (EM) reports

\begin{tabular}{|c|c|c|c|c|c|c|c|c|}
\hline & \multicolumn{4}{|c|}{$\begin{array}{l}\text { Self-reported PWU frequency } \\
\quad(\mathrm{n}=116)\end{array}$} & & \multicolumn{3}{|c|}{$\begin{array}{l}\text { EM-reported PWU frequency } \\
(\mathrm{n}=116)\end{array}$} \\
\hline & & $\mathrm{B}$ & $\beta$ & $\mathrm{p}$ & & B & $\beta$ & $\mathrm{p}$ \\
\hline \multicolumn{9}{|l|}{ Step 1} \\
\hline & Boredom & -0.05 & -0.51 & 0.61 & Boredom & -0.55 & -0.19 & 0.07 \\
\hline & No time & -0.13 & -0.18 & 0.07 & No time & -0.57 & -0.29 & 0.01 \\
\hline & Moral norms & -0.16 & -0.25 & 0.01 & Moral norms & -0.58 & -0.3 & $<.01$ \\
\hline & Group norms & 0.17 & 0.3 & $<.01$ & Group norms & 0.32 & 0.19 & 0.06 \\
\hline & $\mathrm{EM}$ & 0.57 & 0.26 & 0.03 & EM & 1.21 & 0.15 & 0.14 \\
\hline & Guidelines & 0.05 & 0.12 & 0.22 & Guidelines & -0.16 & -0.11 & 0.45 \\
\hline \multicolumn{9}{|l|}{ Step 2} \\
\hline & $\begin{array}{l}\text { Boredom*No } \\
\text { time } \\
\text { R-squared }=.04\end{array}$ & 0.05 & 0.22 & 0.42 & $\begin{array}{l}\text { Boredom*No } \\
\text { time } \\
\text { R-squared }=.10\end{array}$ & 0.25 & 0.38 & 0.18 \\
\hline & $\begin{array}{l}\text { Moral*Group } \\
\text { R-squared }=.20\end{array}$ & 0.03 & 0.19 & 0.39 & $\begin{array}{l}\text { Moral*Group } \\
\text { R-squared }=.19\end{array}$ & -0.2 & -0.47 & 0.04 \\
\hline & $\begin{array}{l}\text { Moral*Guidelines } \\
\text { R-squared }=.016\end{array}$ & -0.06 & -0.22 & 0.01 & $\begin{array}{l}\text { Moral*Guidelines } \\
\text { R-squared }=.33\end{array}$ & 0.002 & 0.002 & 0.98 \\
\hline
\end{tabular}

Multicolinearity was checked with tolerance statistics. Tolerance scores are equal to 1 minus the $r$-squared of the regression of each predictor variable on all of the other predictor variables, while ignoring the criterion variable. A tolerance score for a variable approaching zero would indicate that most of that variable's variance is explained by the other predictor variables in the regression model (Conner, 2002). None of the tolerance scores in the current research's regression analyses fulfilled that condition, indicating that the assumption of linearity was not violated.

Regression models assume that the error deviations are uncorrelated. This independence assumption is assessed through the Durbin-Watson statistic, where values below .80 tend to indicate autocorrelations. In the present study, the Durbin-Watson statistics in the two-moderated hierarchical regressions were 1.88 and 1.98 indicating that the independence assumption was not violated.

Table 3: Results of moderated hierarchical regression analyses testing the influences of boredom and not-having-time electronic monitoring and PWU guidelines and those of moral norms and work group norms on Personal Web Use (PWU) frequencies measured through self-report and through electronic monitoring (EM) reports.

We found partial support for H5. Group norms had a moderating effect on the link between moral norms and PWU only for EM-reported PWU $(\beta=-.47, p=.04)$ and not for self-reported PWU $(\beta=.19, p=.39)$.

Contrary to $\mathrm{H} 6$ we did not find an interaction between workplace boredom and perceived time to engage in PWU for either the self-reported measure $(\beta=.22, \mathrm{p}=.42)$ or the EM-reported measure $(\beta=.38, \mathrm{p}=18)$.

\section{Discussion}

\subsection{Implications for Research and Practice}

The current study both confirms and challenges existing research in an attempt to shed light on some of the complexities associated with the widespread PWU phenomenon in the modern workplace. Our findings highlight 
some of the existing gaps between researchers' recommendations, organizational initiatives, and employee actions and perceptions about PWU. We examine some of these similarities and differences in the following paragraphs.

\subsubsection{Competing Definitions of PWU}

The discrepancy between impact on self-reported PWU and EM-reported PWU potentially explains why this behavior persists even in heavily monitored environments. On average, individuals in this study tended to underreport their PWU. This finding in itself may appear to be somewhat 'common sense', yet it has so far not been empirically demonstrated. The finding is of special interest in the context of this study seeing that the introduction of PWU guidelines and electronic monitoring as effective tools to reduce or prevent PWU has historically been supported by research data based on self-report PWU. One plausible explanation for the differences found in this study is that users differed in their definition of what constitutes PWU activities compared to the definition held by the IT Department responsible for programming the electronic monitoring (EM) software. For example, EM may identify attempts of reading the daily newspaper as PWU and block access, regardless whether it is actually a typical part of some roles within that organization.

As explained by Mahatanankoon, Anandarajan \& Igbaria (2004), users and IT may differ in how they regard actual and/or blocked PWU activity conducted during official breaks and this may explain the underreporting noted in this existing study. Users may perceive that during this time they are not 'at work' and hence tend not to report their actual and/or attempted PWU during this time. A study by Stratton (2010) suggests that individuals engaging in PWU often interpret their experience "as a vehicle to escape from current work surroundings" (p. 398). Ownership of their time and space is likely an indication that users resisted the EM since it violated their interpretation of PWU as a reasonable escape instead an explicit violation of policy. The EM system and existing policy in the researched organization (as probably in most organizations using EM systems) prohibit such behavior and typically do not differentiate between work and personal time.

Differences between EM-reported PWU and self-reported PWU may also be related to the alignment of online activities with one's job requirements. For instance in a study by Polzer-Debruyne (2008), one participant stated that, "Often I am traveling or working odd hours for my employer, [so] the ability to manage some personal details (like banking) is beneficial to me being able to stay at work. The boundaries between personal and work time are so blurred, I found it difficult to answer some of these questions - for example, I spent Friday night/Saturday and Sunday working - but feel no guilt in paying a bill from my work station” (Polzer-Debruyne, 2008, p. 232). Similar attitudes to working hours and PWU are conceivable in this current study. Future research perhaps should examine the sense of entitlement to PWU in exchange for travelling, working overtime, and/or unscheduled hours. It may also be interesting to investigate whether the reported difference in PWU exists for different role types. It may be possible that for some roles the boundaries of what is included in work-related activities and what is not is clearer than for others.

\subsubsection{Push and Pull Factors Exposed}

While our findings reveal differences between self-reported and EM-reported data they also reveal that there appear to be similarities with respect to identifying why individuals differ in the extent of their PWU. Individuals' moral norms about PWU appear to have a strong impact on their online behaviors, regardless of how PWU is measured. The effect of workgroup norms on PWU appears to differ based on the way PWU is measured. Workgroup norms influenced differences in individuals' PWU only when measured through self-report. When investigating PWU through EM-reported data, in turn, those findings were statistically insignificant. Further, using the EM-reported measure, workgroup norms had the hypothesized moderating, push-effect on the relationship between individuals' moral norms and their PWU frequency. Blanchard and Henle (2008) suggest that workgroup norms only predict minor forms of PWU (e.g., webmail, news, or travel) instead of more severe forms of PWU (e.g., gambling, pornography and music downloads). If that is the case, the discrepancy found in this study may again be due to differences in defining the aspect of non-work activities between employees and the IT Department. Essentially, employees may define certain Internet behaviors as legitimate, minor 'perks' of their job and/or as within their current work requirements when self-reporting PWU. These activities may be those same forms of PWU considered normative by their workgroup. The IT Department, on the other hand, takes a more blanketed approach when defining which activities are within customary work requirements and thereby discounting individual needs to uphold existing policy. Assuming that managers sustain this blanketed approach even when EM is no longer able to control PWU, say on personal devices, our findings suggest that examining different definitions of the PWU parameters may be a helpful first step when developing usage policies. 
Surprisingly, though we predicted workplace boredom would lead to PWU as a diversion or a way of creating meaning, the results did not bear this out. This deviates greatly from existing research (Eastin, Glynn \& Griffiths, 2007; Polzer-Debruyne, 2008). One possible explanation of this finding may be because our study's respondents reported relatively low levels of workplace boredom. The respondents' roles in the present study ranged from being part of the Public Safety and District Attorneys' office to Park Rangers and Parking Wardens. It is possible that employees in these roles experience less boredom in their work and find it more meaningful than employees of different work contexts and sectors examined in previous studies on public sector motivation (Bright, 2008; Buelens \& Van den Broeck, 2007; Wright, 2007). It is also possible that respondents in the current study found other less risky avenues to decrease any existing boredom, such as taking longer lunch breaks or making personal phone calls. Researchers may want to further investigate the link between boredom, work motivation, and PWU by focusing on comparative differences in tolerance toward PWU and PWU pervasiveness across a variety of organizations.

Examining individual differences such as personal moral norms can further contribute to the understanding of what pulls some employees away from engaging in PWU than others. If it is important for organizations to limit PWU even in the age of portable devices, then we suggest a number of action steps to consider. First, electronic monitoring and PWU guidelines should be seen as parameters rather than as tools that can prevent PWU, especially with the increased use of Internet-enabled devices that are often outside the practical control of the organization. Creating clarity and trust, appealing to moral obligations, and maintaining a healthy proportion of pragmatism may be the best ways for managers to approach employee PWU. Second, management should refine their PWU policies and engage in open and honest communication with their employees about respective interests to determine alignment between what is legitimate and prohibited. Lastly, we recommend employers consider including psychometric testing of moral norms during selection and to observe and analyze the norms existing in different work groups.

Our findings have implications for scholars, but also for managers and employees. The extent to which employees feel entitled to use PWU, engage in it to escape, perceive it to be none of the employer's business, or do it 'automatically' without thinking, can potentially be a staff engagement indicator for employers. The results of this study encourage employers to move beyond initial assumptions about PWU (e.g., 'this person is constantly on the net and therefore he/she is counterproductive'). Observing the extent of PWU activities should not be the end. It should be the start of critical investigation into possible reasons before taking disciplinary action.

\subsection{Limitations and Opportunities}

Our research provides partial support for the idea that enabling and inhibiting factors on PWU exist and interact within individuals and their work environment. We also highlight that employee and employer definitions and measures of PWU may not necessarily be the same. Current scholarly explanations on what influences PWU appear to rest on the assumption that self-reported and EM-reported PWU frequencies are comparable (e.g., Blanchard \& Henle, 2008; Eastin, Glynn \& Griffiths, 2007; Lee, Lee \& Kim, 2004; Lim, 2002; Mahatanankoon, Anandarajan \& Igbaria, 2004; Manrique De Lara, 2006; Shaw \& Gant, 2002). We found that the two measures of PWU (self-reported access or try to access and EM-reported blocking of attempted access) are not identical. Such a difference is important because it highlights how and why researchers (basing it on self-report) and organizations (basing it on EM-reports) differ in their understanding of PWU. We sought to bring this out into the open to encourage discussion about how to best manage PWU. For example, from the employees' perspectives self-reporting on what they see as PWU, the results of this study suggest that electronic monitoring is effective. From a management perspective, however, this appears to be less the case when examining the EM data. Similarly, the EM data reveal that PWU is likely to be influenced by employee boredom, but the respondents' self-report data suggest that boredom does not play such a role. Future studies perhaps should delve deeper into the differences of perspective on PWU and its determinants and possibly investigate the application of theoretical approaches such as the fundamental attribution error.

It is important to keep in mind other limitations and opportunities associated with this study. First, the research was conducted with a single public sector organization that has very strict EM reporting processes and reportedly zero-tolerance to PWU. Different contexts (i.e., leniency towards PWU) may show different patterns. Future studies could address this through direct comparison of data from different organizations.

Secondly, it is possible that time differences in collection between the EM-reported and self-reported PWU data may have had an impact on respondents' PWU. Future studies may therefore want to collect PWU data from all sources at the same time to limit the influence of such confounding. It may also be beneficial, time and finances permitting, to combine quantitative and ethnographic data collection from the same organization and at the same time, giving a more holistic picture of potential influences on PWU. Such research may then include examinations of employee 
attitudes and emotional reactions to workplace monitoring employee and supervisor relationships, and other possible avenues to express lack of job satisfaction, boredom, and/or resistance to actual or perceived constraints within the working environment.

Lastly, this study only examined PWU using the organization's workstations. As previously noted, we did not examine the notion of 'time theft' through engaging in activities such as texting or conversing via Twitter on smartphones or tablets. The permanence of mobile technology use may present an additional tool for individuals to engage in PWU for which the organization may have little control (Hislop \& Axtell, 2011). Will we see transference of PWU from workplace computers to Smartphones and tablet devices? A study by the Information Systems Audit and Control Association (ISACA) (2011) found that employees who have access to Internet on the job tend to utilize both personal devices ('bring your own device' BYOD) and organizational technology to conduct personal work at work. It is interesting to note that the ISACA (2011) study also revealed that very few respondents indicated any existing policies prohibiting or limiting BYOD usage. This finding is similar to a more recent industry study by IT staffing firm Modis (The Debate Over BYOD, 2012). This potentially new avenue for non-work behaviors may be of great interest to researchers and practitioners alike seeking to further develop and manage the PWU construct.

\subsection{Conclusion}

Organizations continue to implement EM systems and usage policies to curb employee Internet behaviors perceived as counterproductive by the organization (Ugrin \& Pearson, 2013). A recent report (Polk-Lepson Research Group, 2013) indicated that, "on average, half of all new college graduate employees (48.8\%) abuse IT in some way" (p. 9), which includes PWU in the workplace. Given the growth in both EM and PWU, it is even more critical that organizations reflect on the abovementioned findings when drawing conclusions across the entire organization and making enterprise-wide technology policy recommendations regarding the management and control of PWU. Knowing what may push users toward PWU and what may lead users to pull away are central to effective human and information resource management. Conflating usage policies and EM systems with user compliance is problematic. As our findings reveal, the competing definitions of PWU can challenge managerial assumptions about relative policy and EM effectiveness.

By clarifying why self-reported PWU and EM-reported PWU differ significantly can help practitioners come to grips with the ever-increasing phenomenon of PWU. Fairhurst and Zoller (2008) assert that leaders must learn from employees if they wish to deal with such examples of resistance to organizational policy. "Genuine attention to employee experiences and their reactions to managerial actions would allow leaders to diagnose problems, affirm emotions and create dialogue" (p. 144). Drawing a clearer picture of PWU incorporating the employee perspective could reduce mutual misunderstanding and lead to more useful policies and EM efficacy.

In summary, our findings challenge researchers and managers to be more precise when defining the activity and time components of their PWU concepts. At the same time, the findings encourage researchers and practitioners alike to be aware of context, such as the individual and group norms, boredom, and time pressures. While there are numerous opportunities for scholars to continue studying this phenomenon, our study furthers not only conceptual understanding, but also presents practical implications for managers to consider when navigating the complex nature of PWU at work.

\section{Acknowledgements}

Throughout this multi-year project, various individuals and institutions supported this scholarship. We are grateful to our undergraduate and graduate student research assistants, Jovanni Mahonez, Zhang Xiaojing, and Sasiya Supprakit for their countless hours providing support in the data collection. Lastly, we are immensely appreciative for the collaborative relationship with the employees and management at the research site.

\section{References}

Ajzen, I. (1991). The theory of planned behavior. Organizational Behavior and Human Decision Processes, 50(2), 179-211. http://dx.doi.org/10.1016/0749-5978(91)90020-T

Ajzen, I. (2002). Perceived behavioral control, self-efficacy, locus of control, and the theory of planned behavior. Journal of Applied Social Psychology, 32, 665-683. http://dx.doi.org/10.1111/j.1559-1816.2002.tb00236.x

Ajzen, I. (2002a). Constructing a TpB questionnaire: Conceptual and methodological considerations. Retrieved August 12, 2003, from www.unix.oit.umass.edu/ aizen/pdf/tpb.measurement.pdf 
Anandarajan, M. \& Simmers, C. (2002). Factors influencing web access behavior in the workplace: A structural equation approach. In M. Anandarajan and C. Simmers (Eds.), Managing web usage in the workplace: A social, ethical and legal perspective (pp. 44-66). Melbourne: IRM Press. http://dx.doi.org/10.1089/cpb.2006.9.325

Anandarajan, M., Paravastu, N., \& Simmers, C. (2006). Perceptions of personal web usage in the workplace: A Q-methodology approach. CyberPsychology \& Behavior, 9(3), 325-335.

Anandarajan, M., Simmers, C., \& Igbaria, M. (2000). An exploratory investigation of the antecedents and impact of internet-usage: An individual perspective. Behavior and Information Technology, 19(1), 69-85. http://dx.doi.org/10.1080/014492900118803

Bandura, A. (1977). Social learning theory. Englewood Cliffs, NJ: Prentice-Hall

Banerjee, D., Cronan, T. P., \& Jones, T. W. (1998). Modeling IT ethics: A study in situational ethics. MIS Quarterly, 31-60. http://dx.doi.org/10.2307/249677

Barbalet, J. M. (1999). Boredom and social meaning. British Journal of Social Psychology, 5(4), 631-646.

Barbuto, J. E., \& Scholl, R. W. (1998). Motivation Sources Inventory: Development and validation of new scales to measure an integrative taxonomy of motivation. Psychological Reports, 82, 1011-1022. http://dx.doi.org/10.2466/pr0.1998.82.3.1011

Barrett, P. (2002). Single item/attribute psychometrics - Can it be done? (Presentation). Auckland: I/O Psychologist Interest group.

Beck, L., \& Ajzen, I. (1991). Predicting dishonest actions using the theory of planned behavior. Journal of Research in Personality, 25, 285-301. http://dx.doi.org/10.1016/0092-6566(91)90021-H

Belicove, M. E. (2011). Do social tools really hurt employee productivity? Retrieved August 12, 2012, from http://www.entrepreneur.com/blog/219719

Bellman, S., Lohse, G. L., \& Johnson, J. E. (1999). Predictions of online buying behavior. Communications of the ACM, 42(12), 32-38. http://dx.doi.org/10.1145/322796.322805

Benesch. (2011). NLRB Issues report presenting recent developments arising in the context of social media. Labor \& Employment Bulletin. Retrieved November 5, 2011, from http://www.beneschlaw.com/nlrb-issues-report-presenting-recent-case-developments-arising-in-the-context-of-s ocial-media-10-07-2011/

Blanchard, A. L., \& Henle, C. A. (2008). Correlates of different forms of cyberloafing: The role of norms and external locus of control. Computers in Human Behavior, 24, 1067-1084. http://dx.doi.org/10.1016/j.chb.2007.03.008

Blau, G., Yang, Y., \& Ward-Cook, K. (2004). Testing a measure of cyberloafing. Journal of Allied Health, 35, 9-17.

Blumenfeld, W. (2005). Cyberbulling: A new variation on an old theme. Present at Abuse I: The Darker Side of Human-Computer Interaction. Retrieved August 2, 2012 from, http://agentabuse.org/blumenfeld.pdf

Braithwaite, V. A., \& Scott, W. A. (1991). Values. In J. P. Robinson, P. R. Shaver \& L. S. Wrightsman (Eds.), Measures of personality and social psychological attitudes. San Diego: Academic Press. http://dx.doi.org/10.1016/B978-0-12-590241-0.50016-2

Bright, L. (2008). Intrinsic motivation in public organizations. In Charles Wankel (Ed.), The Handbook of 21st Century Management (Vol. 2, pp.193-202). Sage Publications.

Bruursema, K., Kessler, S.R., \& Spector, P.E. (2011). Bored employees misbehaving: The relationship between boredom and counterproductive work behavior. Work \& Stress. 25(2), 93-107. http://dx.doi.org/10.1080/02678373.2011.596670

Buelens, M., \& van den Broeck, H. (2007, Jan/Feb). An analysis of differences in work motivation between public and private sector organizations. Public Administration Review, 65-74. http://dx.doi.org/10.1111/j.1540-6210.2006.00697.x

Conner, D. S. (2002). The role of equity sensitivity in organizational justice perceptions. Unpublished dissertation, Tallahasseee, FL; Florida State University. 
Conner, M., \& Armitage, C., J. (1998). Extending the theory of planned behavior: A review and avenues for further

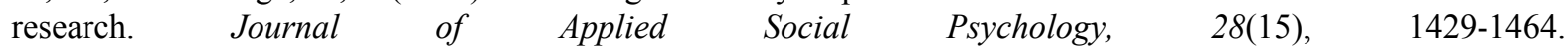
http://dx.doi.org/10.1111/j.1559-1816.1998.tb01685.x

Conner, N., \& McMillan, B. (1999). Interaction effects in the theory of planned behavior: Studying cannabis use. British Journal of Social Psychology, 38, 195-222. http://dx.doi.org/10.1348/014466699164121

Couper, M. P. (2000). Web surveys: A review of issues and approaches. Public Opinion Quarterly, 64, 464-494. http://dx.doi.org/10.1086/318641

Devaney, E. E. (2006). Excessive Indulgences. Personal use of the Internet at the Department of the Interior (Report No. Y-EV-MOA-0002-2006). Washington D.C: United States Department of the Interior.

Eastin, M. S., Glynn, C. J., \& Griffiths, R. P. (2007). Psychology of communication technology use in the workplace. CyberPsychology and Behavior, 10(3), 436-443. http://dx.doi.org/10.1089/cpb.2006.9935

Fairhurst, G.T., \& Zoller, H. (2008). Resistance, dissent and leadership in practice. In S.P. Banks (Ed.), Dissent and the failure of leadership: New horizons in leadership studies (pp. 135-148). Edward Elgar Publishing.

Feldman, D. C. (1984). The development and enforcement of group norms. The Academy of Management Review, $9(1), 47-53$.

Festinger, L. (1954). A theory of social comparison. Human Relations, 7, 117-140. http://dx.doi.org/10.1177/001872675400700202

Fraisse, P. (1963). The psychology of time. New York: Harper and Row.

Goethals, G. R. (1986). Social comparison theory: Psychology from the lost and found. Personality and Social Psychology Bulletin, 12, 261-278. http://dx.doi.org/10.1177/0146167286123001

Gordan, L. A., Loeb, M. P., Lucyshyn, W., \& Richardson, R. (2005, September). CSI-FBI Computer Crime and Security Survey. Retrieved December 1, 2005, from www.gocsi.com

Gordon, S., \& Qingxiong, M. (2003). Convergence of Virus Writers and Hackers: Fact or Fantasy? Cupertine, CA: Symantec.

Greenberg, J., \& Scott, K., S. (1996). Why do workers bite the hands that feed them? Employee theft as a social exchange process. Research in Organizational Behavior, 18, 111-156.

Hill, A. B., \& Perkins, R. E. (1985). Towards a model of boredom. British Journal of Psychology, 76, 235-240. http://dx.doi.org/10.1111/j.2044-8295.1985.tb01947.x

Hislop, D., \& Axtell, C. (2011). Mobile phones during work and non-work time: A case study of mobile, non-managerial workers. Information and Organization, 21, 41-56. http://dx.doi.org/10.1016/j.infoandorg.2011.01.001

Information Systems Audit and Control Association (ISACA). (2011). 2011 ISACA Shopping on the Job Survey: Online Holiday Shopping and BYOD Security. Retrieved January 2012, from http://www.isaca.org/SiteCollectionDocuments/2011-US-Online-Holiday-Shopping-Key-Findings.pdf

Jaccard, J., Turisi, R., \& Wan, C. K. (1990). Interaction effects in multiple regression. Newbury Park, CA: Sage.

Joinson, A. (1999). Social desirability, anonymity, and Internet-based questionnaires. Behavior Research Methods, Instruments and Computers, 31(3), 433-438. http://dx.doi.org/10.3758/BF03200723

Kalkbrenner, J., \& McCampbell, A. (2011). The advent of smartphones: A study on the effect of handheld electronics on personal and professional productivity. Journal of Applied Global Research, 4(8), 1-9.

KensingtonSwan. (2003). Email and internet use in the workplace. Some surprising statistics. Wellington: KensingtonSwan Lawyers.

Kiesler, S., \& Sproull, L. S. (1986). Response effects in the electronic survey. Public Opinion Quarterly, 50, 402-413. http://dx.doi.org/10.1086/268992

Kim, S. J., \& Byrne, S. (2011). Conceptualizing personal web usage in work contexts: A preliminary framework. Computers in Human Behavior, 27(6), 2271-2283. http://dx.doi.org/10.1016/j.chb.2011.07.006

Lee, T., W. (1986). Toward the development and validation of a measure of job boredom. Manhattan College Journal of Business, 15(1), 22-27. 
Lee, Z., Lee, Y., \& Kim, Y. (2004). Personal web usage in organizations. In M. Anandarajan and C. Simmers (Eds.), Personal Web Usae in the workplace: A guide to effective human resources management. Melbourne: Information Science Publishing. http://dx.doi.org/10.4018/978-1-59140-148-3.ch002

Leonard, L. N, Cronan, T. P., \& Kreie, J. (2004). What influences IT ethical behavior intentions - planned behavior, reasoned action, perceived importance or individual characteristics? Information and Management, 42, 143-158. http://dx.doi.org/10.1016/j.im.2003.12.008

Lim, V. K. G.. (2002). The IT of loafing on the job: cyberloafing, neutralizing and organizational justice. Journal of Organizational Behavior, 23, 675-694. http://dx.doi.org/10.1002/job.161

Lim, V., K, G, Teo, T. S. H., \& Loo, G. L. (2002). How do I loaf here? Let me count the ways. Communications of the ACM, 45(1), 66-70. http://dx.doi.org/10.1145/502269.502300

Mahatanankoon, P., \& Igbaria, M. (2004). Impact of personal internet usage on employee's well-being. In M. Anandarajan and C. Simmers (Eds.), Personal Web Usage in the workplace: A guide to effective human resources management (pp. 246-263). Melbourne: Information Science Publishing. http://dx.doi.org/10.4018/978-1-59140-148-3.ch013

Mahatanankoon, P., Anandarajan, M., \& Igbaria, M. (2004). Development of a measure of personal web usage in the workplace. CyberPsychology and Behavior, 7(1), 93-104. http://dx.doi.org/10.1089/109493104322820165

Malachowski, D., \& Simonini, J. (2006). Wasted time at work still costing companies billions in 2006. Retrieved September 1, 2007, from http://salary.com/sitesearch/layoutscripts/sisl_display.asp?filename=andpath=/destinationsearch/personal/par54 2_body.html

Manrique de Lara, P. Z. (2006). Fear in organizations: Does intimidation by formal punishment mediate the relationship between interactional justice and workplace Internet deviance? Journal of Managerial Psychology, 21(6), 580-592. http://dx.doi.org/10.1108/02683940610684418

March Maddness Survey. (2012). Modis. Retrieved March 18, 2013, from http://www.modis.com/about/press-room/survey-downloads/march-madness-survey-media-deck-2012.pdf

Mastrangelo, P., Everton, W., \& Jolton, J. (2006). Personal Use of Work Computers: Distraction versus Destruction. CyberPsychology \& Behavior, 9(6), 730-741. http://dx.doi.org/10.1089/cpb.2006.9.730

Mattioli, D. (2013). For Penny's heralded boss, the shine is off the apple. Wall Street Journal. Retrieved March 7 , 2013, from http://online.wsj.com/article/SB10001424127887324338604578324431500236680.html

McElhatton, J. (2009, September 28). EXCLUSIVE: Porn surfing rampant at U.S. science foundation. The Washington Times. $\quad$ Retrieved September 9, 2009, from http://www.washingtontimes.com/news/2009/sep/29/workers-porn-surfing-rampant-at-federal-agency/?page=2

McElhatton, J. (2010, February 2). SEC workers investigated for porn-surfing. The Washington Times. Retrieved March 24, 2010, from http://www.washingtontimes.com/news/2010/feb/02/sec-workers-investigated-for-viewing-porn-at-work/?page $=2$

Milbourn, III, G. C. (2003). Inappropriate personal use of the Internet jeopardizes the security and privacy of taxpayer data (Report No. 2003-2020-2133). Washington D.C: United States Department of Treasury.

Mirchandani, D., \& Motwani, J. (2003). Reducing Internet abuse in the workplace. Advanced Management Journal, 45, 66-70.

Nagy, M. S. (2002). Using a single-item approach to measure facet job satisfaction. Journal of Occupational and Organizational Psychology, 75, 77-86. http://dx.doi.org/10.1348/096317902167658

Nalbandian, J., O’Neil Jr., R., \& Wilkes, M. (2013). Contemporary Challenges in Local Government: Evolving Roles and Responsibilities, Structures, and Processes. Public Administration Review, 73(4), 567-574. http://dx.doi.org/10.1111/puar.12059

Pinaa, V., Torresa, L., \& Royoa, S. (2010). Is E-Government Promoting Convergence Towards More Accountable Local Governments? International Public Management Journal, 13(4), 350-380. http://dx.doi.org/10.1080/10967494.2010.524834 
Polk-Lepson Research Group. (2013). 2013 Professionalism in the Workplace. Retrieved March 22, 2013, from http://www.ycp.edu/media/yorkwebsite/cpe/York-College-Professionalism-in-the-Workplace-Study-2013.pdf

Polzer-Debruyne, A. M. (2002). Electronic monitoring and Internet use at work / university. Unpublished manuscript, The University of Auckland, New Zealand.

Polzer-Debruyne, A. M. (2008). Psychological and Workplace attributes that influence Personal Web Use (PWU). Unpublished doctoral dissertation, Massey University, Albany, New Zealand.

Richardson, R. (2003). CSI-FBI Computer Crime and Security Survey. Retrieved December 31, 2003, from www.gocsi.com

Richardson, R. (2008). CSI Computer Crime and Security Survey. Retrieved August 31, 2008, from www.gocsi.com

Salancik, G. R., \& Pfeffer, J. (1978). A social information processing approach to job attitudes and task design. Administrative Science Quarterly, 23(2), 224-253. http://dx.doi.org/10.2307/2392563

Schwartz, S. H. (1977). Normative influences on altruism. In L. Berkowitz (Ed.), Advances in Experimental Social Psychology (Vol. 10, pp. 221-279). New York: Academic Press.

Schwartz, S. H., \& Tessler, R. C. (1972). A test of a model for reducing measured attitude-behavior discrepancies. Journal of Personality and Social Psychology, 24(2), 225-263. http://dx.doi.org/10.1037/h0033365

Shaw, L., \& Gant, L. (2002, April). In Defense of the Internet: The Relationship between Internet Communication and Depression, Loneliness, Self-Esteem, and Perceived Social Support. CyberPsychology and Behavior, 5(2), 157-171. http://dx.doi.org/10.1089/109493102753770552

Sherif, M. (1961). Conformity-deviation, norms and group relations. In I. A. Berg \& B. M. Bass (Eds.), Conformity and deviation (pp. 159-198). New York, NY: Harper and Brothers. http://dx.doi.org/10.1037/11122-006

Skinner, B., F. (1938). The behavior of organisms. New York: Appleton-Century-Crofts.

Solomon, P. (1961). Sensory deprivation. Oxford: Oxford University Press. http://dx.doi.org/10.4159/harvard.9780674864818

Stajkovic, A. D., \& Luthans, F. (1998). Social cognitive theory and self-efficacy. Organizational Dynamics, 26(4), 62-74. http://dx.doi.org/10.1016/S0090-2616(98)90006-7

Stratton, M. T. (2006). On the messiness of emotions: An ethnographic study of personal web usage and electronic monitoring in the workplace. University at Albany, State University of New York. ProQuest Information and Learning Company Publishers.

Stratton, M. T. (2010). Uncovering a new guilty pleasure: A qualitative study of the emotions of personal web usage at work. Journal of Leadership and Organization Studies, 17, 392-410. http://dx.doi.org/10.1177/1548051809350893

Svendsen, L. (2005). A philosophy of boredom. London: Reaktion Books.

The Debate Over BYOD. (2012). Modis. Retrieved March 18, 2013, from http://www.modis.com/it-insights/it-white-papers/downloads/BYOD-US-WP-singles.pdf

Ugrin, J. C., \& Pearson, J. M. (2008). Exploring Internet abuse in the workplace: how can we maximize deterrence efforts? Review of Business, 28(2), 13-28.

Ugrin, J. C., \& Pearson, J. M. (2013). The effects of sanctions and stigmas on cyberloafing. Computers in Human Behavior, 29(3), 812-820. http://dx.doi.org/10.1016/j.chb.2012.11.005

Vitak, J., Crouse, J., \& LaRose, R. (2011). Personal Internet use at work: Understanding cyberslacking. Computers in Human Behavior, 27(5), 1751-1759. http://dx.doi.org/10.1016/j.chb.2011.03.002

Vorobyov, G. D. (2005). Computer and internet use in the work place: A common sense approach. The Psychologist-Manager Journal, 8(2), 177-187. http://dx.doi.org/10.1207/s15503461tpmj0802_8

Workman, M. (2009). A field study of corporate employee monitoring: Attitudes, absenteeism, and the moderating influences of procedural justice perceptions. Information and Organization, 19, 218-232. http://dx.doi.org/10.1016/j.infoandorg.2009.06.001

Wright, B. (2007, Jan/Feb). Public service and motivation: Does mission matter? Public Administration Review, 54-64. http://dx.doi.org/10.1111/j.1540-6210.2006.00696.x 


\section{Appendices}

Appendix A. Relevant survey items

Below are those items referenced in this study, which were part of a larger survey, conducted with the participating organization.

The first set of questions investigates some of your current Internet use at work and the systems and policies in your workplace.

Please remember, none of your comments and responses will be reported anywhere as individual answers!

Can you please give an estimate how often you access or try to access the Internet at work for personal interest in an average week?
- Never
○ Only once
○ 2-10 times
○ 11-20 times
- 21-30 times
- 31-40 times
○ 41-50 times
- 51-60 times
- 61-70 times
- Over 70 times

When you access the Internet at work dominantly for personal interest, what type of websites do you tend to access? (Check as many as apply)
- Personal email
○ News
○ Sports
- Weather
○ Shopping
○ Banking
○ Job Search
- Personal investment
- Travel
○ Recreation
- Art / Culture
○ Adult content
○ Entertainment
- Personal, external business
○ Websites related to my hobby
- Legal advice
○ Other (please list / specify) 
The following table summarises survey items and response scale relevant to this study that were presented to respondents under different headings within the main survey

\begin{tabular}{|c|c|c|c|c|c|c|c|}
\hline & $\begin{array}{l}\text { Strongly } \\
\text { disagree }\end{array}$ & $\begin{array}{c}\text { Moderately } \\
\text { disagree }\end{array}$ & Disagree & Agree & $\begin{array}{c}\text { Moderately } \\
\text { agree }\end{array}$ & $\begin{array}{c}\text { Strongly } \\
\text { agree }\end{array}$ & $\begin{array}{c}\text { I am not } \\
\text { sure }\end{array}$ \\
\hline \multicolumn{8}{|l|}{$\begin{array}{l}\text { My colleagues access } \\
\text { the Internet at work for } \\
\text { personal interest }\end{array}$} \\
\hline \multicolumn{8}{|l|}{$\begin{array}{l}\text { My colleagues at work } \\
\text { would not mind if I } \\
\text { access the Internet at } \\
\text { work for personal } \\
\text { interest }\end{array}$} \\
\hline \multicolumn{8}{|l|}{$\begin{array}{l}\text { My supervisor accesses } \\
\text { the Internet at work for } \\
\text { personal interest }\end{array}$} \\
\hline \multicolumn{8}{|l|}{$\begin{array}{l}\text { My supervisor does not } \\
\text { mind if I access the } \\
\text { Internet at work for } \\
\text { personal interest }\end{array}$} \\
\hline \multicolumn{8}{|l|}{$\begin{array}{l}\text { Accessing the Internet } \\
\text { at work for personal } \\
\text { interest would go } \\
\text { against my principles }\end{array}$} \\
\hline \multicolumn{8}{|l|}{$\begin{array}{l}\text { I would feel guilty } \\
\text { accessing the Internet at } \\
\text { work for personal } \\
\text { interest }\end{array}$} \\
\hline \multicolumn{8}{|l|}{$\begin{array}{l}\text { It would be morally } \\
\text { wrong for me to access } \\
\text { the Internet at work for } \\
\text { personal interest }\end{array}$} \\
\hline \multicolumn{8}{|l|}{$\begin{array}{l}\text { I simply don't have the } \\
\text { time to access the } \\
\text { Internet at work for } \\
\text { personal interest }\end{array}$} \\
\hline \multicolumn{8}{|l|}{$\begin{array}{l}\text { I often get bored at } \\
\text { work }\end{array}$} \\
\hline \multicolumn{8}{|l|}{$\begin{array}{l}\text { My work is } \\
\text { monotonous }\end{array}$} \\
\hline \multicolumn{8}{|l|}{ I find my job dull } \\
\hline \multicolumn{8}{|l|}{$\begin{array}{l}\text { My work goes by too } \\
\text { slowly }\end{array}$} \\
\hline \multicolumn{8}{|l|}{$\begin{array}{l}\text { I get mentally sluggish } \\
\text { during the day }\end{array}$} \\
\hline \multicolumn{8}{|l|}{$\begin{array}{l}\text { Time seems to go by } \\
\text { slowly at work }\end{array}$} \\
\hline \multicolumn{8}{|l|}{$\begin{array}{l}\text { There are long periods } \\
\text { of boredom at my work }\end{array}$} \\
\hline $\begin{array}{l}\text { The job seems to be } \\
\text { repetitive }\end{array}$ & & & & & & & \\
\hline
\end{tabular}


Appendix B. Principle Component Analysis (Oblimin rotation) results for moral norm, boredom and work group norm

\begin{tabular}{lccc}
\hline Items & Component & & \\
\hline & 1 & 2 & 3 \\
PWU against principles & & 0.88 & \\
Feel guilty if PWU & & 0.88 & \\
PWU morally wrong & & 0.84 & \\
Often bored & 0.85 & & \\
Monotonous work & 0.85 & & \\
Job dull & 0.85 & & \\
Work goes slowly & 0.86 & & \\
Mentally sluggish & 0.64 & & \\
Time goes slowly & 0.84 & & \\
Long boredom & 0.82 & & \\
Repetitive work & 0.82 & \\
Colleagues access & & \\
Colleagues don't mind & & 0.81 \\
Supervisor accesses & & 0.87 \\
Supervisor doesn't mind & & \\
\hline
\end{tabular}

Notes: $(n=116), 69 \%$ of all variance explained

Cross loadings shown only for coefficient values $>.1$ 